\title{
ANALISIS EFEKTIVITAS PENERAPAN PAJAK SARANG BURUNG WALET DI KABUPATEN MINAHASA
}

\author{
Pingkan Lapian ${ }^{1}$ \\ Grace B. Nangoi ${ }^{2}$ \\ Steven J. Tangkuman ${ }^{3}$
}

Jurusan Akuntansi, Fakultas Ekonomi dan Bisnis, Universitas Sam Ratulangi, Manado, 95115, Indonesia

Email: ${ }^{1}$ pingkanlapian08@gmail.com

\begin{abstract}
Regional Income is derived from local taxes and levies. Local taxes in Indonesia based on Law No. 28 of 2009 is divided into two, namely, provincial taxes and tax districts / cities. Tax Swallow's Nest is a local tax. The aim of this study was to determine the effectiveness of taxation bird nest in Minahasa district. The analytical method used in this research is descriptive qualitative analysis to give you an idea whether the taxation of bird's nest has been effective or not and how much contribution it provides to the local revenue. The results showed that in 2011 the tax effectiveness of bird's nest of 22.28\%, in 2012 amounted to 109.63\%, in 2013 amounted to $129.48 \%$ and in 2014 amounted to $158.45 \%$ and the tax contributions of bird's nest on Revenue PAD in 2011 amounted to $0.09 \%$, in 2012 amounted to $9.75 \%$, in 2013 amounted to $8.12 \%$ and in 2014 amounted to $6.20 \%$. It can be concluded taxation swallow nest in Minahasa district has been very effective and overall Contributions Tax swallow's nests against local revenue in 2011 through 2014 contributed greatly lacking.
\end{abstract}

Keyword: Effectiveness, Tax Swallow Nest

\section{Latar Belakang}

\section{PENDAHULUAN}

Pendapatan Asli Daerah (PAD) yaitu berasal dari Pajak daerah dan Retribusi Daerah. Pajak daerah di Indonesia berdasarkan Undang-undang nomor 28 tahun 2009 terbagi menjadi dua yaitu, pajak propinsi dan pajak kabupaten/kota. Pembagian ini dilakukan sesuai dengan kewenangan pengenaan dan pemungutan masing-masing jenis pajak daerah pada wilayah administrasi Propinsi atau Kabupaten/kota.

Berdasarkan undang-undang Nomor 28 tahun 2009 ditetapkan lima jenis pajak propinsi dan sebelas jenis pajak kabupaten/kota. Pajak propinsi terdiri dari pajak kendaraan bermotor, bea balik nama kendaraan bermotor, pajak bahan bakar kendaraan bermotor, pajak air permukaan dan pajak rokok. Dan pajak kabupaten/kota terdiri dari Pajak hotel, pajak restoran, pajak hiburan, pajak reklame, pajak penerangan jalan, pajak mineral bukan logam dan batuan, pajak parkir, pajak air tanah, pajak sarang burung wallet, pajak bumi dan bangunan perdesaan dan perkotaan, bea perolehan hak atas tanah dan bangunan.

Pajak Sarang Burung Walet adalah pajak atas kegiatan pengambilan dan/atau pengusahaan sarang burung wallet. Pajak sarang Burung Wallet diatur dalam Undang-undang nomor 28 tahun 2009. Di kabupaten Minahasa Provinsi Sulawesi Utara sendiri terdapat banyak sarang burung wallet. Bisa dilihat di daerah Tanawangko, sepanjang ruas jalan Kalasey serta di daerah Ranowangko dan Rerer. Pajak sarang burung wallet merupakan pajak daerah yang dapat menambah Pendapatan Asli Daerah yang harus di perhatikan.

\section{Tujuan Penelitian}

Tujuan penelitian ini adalah mengetahui efektivitas penerapan Pajak Sarang Burung walet dikabupaten Minahasa dam kontribusi Pajak Sarang Burung Walet terhadap Pendapatan Asli Daerah kabupaten Minahasa.

\section{Pengertian Pajak}

\section{TINJAUAN PUSTAKA}

Pengertian pajak adalah iuran rakyat kepada kas negara berdasarkan undang-undang (yang dapat dipaksakan) dengan tiada mendapat jasa timbal (kontrapretasi) yang langsung dapat ditunjukkan dan yang digunakan untuk membayar pengeluaran umum. 


\section{Fungsi Pajak}

a) Fungsi budgetir

Pajak sebagai sumber dana bagi pemerintah untuk mebiayai pengeluaran-pengeluarannya.

b) Fungsi mengatur

Pajak sebagai alat untuk mengatur atau melaksanakan kebijaksanaan pemerintah dalam bidang social dan ekonomi.

\section{Pajak Daerah}

Pajak Daerah, yang selanjutnya disebut pajak, adalah kontribusi wajib kepada daerah yang terutang oleh orang pribadi atau badan yang bersifat memaksa berdasarkan Undang-undang, dengan tidak mendapatkan imbalan secara langsung dan digunakan untuk keperluan Daerah bagi sebesar-besarnya kemakmuran rakyat.

\section{Tata Cara Pemungutan Pajak}

Pemungutan pajak dilarang diborongkan. Setiap wajib pajak wajib membayar pajak yang terutang berdasarkan surat ketetapan pajak atau dibayar sendiri oleh Wajib pajak berdasarkan peraturan perundang-undangan perpajakan. Wajib pajak yang memenuhi kewajiban perpajakan berdasarkan penetapan Kepala Daerah dibayar menggunakan Surat Ketetapan Pajak Daerah (SKPD) atau dokumen lain yang dipersamakan berupa karcis dan nota perhitungan. Wajib pajak yang memenuhi kewajiban perpajakan sendiri dibayar dengan menggunakan Surat Pemberitahuan Pajak Daerah (SPTPD), Surat Ketetapan Pajak Daerah Kurang Bayar (SKPDKB), dan/atau Surat Ketetapan Daerah Kurang Bayar Tambahan (SKPDKBT).

\section{Pajak Sarang Burung Wallet}

Menurut undang-undang nomor 28 tahun 2009, pajak sarang burung wallet adalah pajak atas kegiatan pengambilan dan/atau pengusahaan sarang burung wallet. Burnung wallet adalah satwa yang termasuk marga collocalia, yaitu collocalia fuchliap haga, collocalia maxina, collocalia esculanta dan collocalia linchi.

Undang-undang nomor 28 tahun 2009 bagian Kelima Belas pasal 72 :

(1) Objek pajak sarang burung wallet adalah pengambilan dan/atau pengusahaan sarang burung wallet.

(2) Tidak termasuk objek pajak sebagaimana dimaksud pada ayat (1) adalah :

a. $\quad$ Pengambilan sarang burung wallet yang telah dikenakan Penerimaan Negara Bukan Pajak (PNBP)

b. Kegiatan pengambilan dari/atau pengusahaan sarang burung wallet lainnya yang ditetapkan dengan peraturan daerah.

Subjek pajak sarang burung wallet dalam pasal 73 :

(1) Subjek pajak sarang burung wallet adalah orang pribadi atau badan yang melakukan pengambilan dan/atau mengusahakan sarang burung wallet.

(2) Wajib pajak sarang burung wallet adalah orang pribadi atau badan yang melakukan pengambilan dan/atau mengusahakan sarang burung wallet.

Dasar pengenaan pajak sarang burung wallet dalam pasal 74 :

(1) Dasar pengenaan pajak sarang burung wallet adalah nilai jual sarang burung wallet.

(2) Nilai jual sarang burung wallet sebagaimana dimaksud pada ayat (1) dihitung berdasarkan perkalian antara harga pasaran umum sarang burung wallet yang berlaku di daerah yang bersangkutan dengan volume sarang burung wallet.

Dalam pasal 75 tarif pajak sarang burung wallet ditetapkan paling tinggi sebesar 10\%, tariff pajak sarang burung wallet ditetapkan dengan peraturan daerah. Sementara itu dalam pasal 76 menyebutkan bahwa besaran pokok pajak sarang burung wallet yang terutang dihitung dengan cara mengalikan tariff sebagaimana dimaksud dalam pasal 75 ayat (2) dengan dasar pengenaan pajak sebagaimana dimaksud dalam pasal 74. Pajak sarang burung wallet terutang dipungut diwilayah daerah tempat pengambilan dan/atau pengusahaan sarang burung wallet.

Di Kabupaten Minahasa sendiri yang mengatur Pajak sarang burung wallet adalah Peraturan Daerah Kabupaten Minahasa Nomor 1 Tahun 2011 Tentang Pajak Daerah. 


\section{Jenis Penelitian}

\section{METODOLOGI PENELITIAN}

Dalam penelitian ini penulis menggunakan jenis data kuantitatif yaitu Laporan Realisasi Anggaran Pajak Daerah Kabupaten Minahasa tahun 2011-2014 dan Laporan Realisasi Anggaran Pendapatan Asli Daerah (PAD) Kabupaten Minahasa dari tahun 2011-2014 yang kemudian dijadikan data kualitatif yaitu dengan mendekripsikan angka-angka tersebut.

\section{Metode Analisis}

Sesuai dengan tujuan dari penelitian ini maka, metode yang digunakan adalah metode analisis deskriptif kualitatif yang bertujuan untuk mendapatkan gambaran yang lebih jelas dan terperinci mengenai suatu keadaan berdasarkan data atau informasi yang telah didapatkan dalam hal ini memberikan gambaran apakah penerapan pajak sarang burung walet sudah efektif atau belum serta seberapa besar kontribusi pajak sarang burung walet terhadap Pendapatan Hasil Daerah (PAD), kemudian dikumpulkan sehingga didapatkan informasi yang diperlukan untuk menganalisa masalah yang ada.

\section{Analisis Efektivitas}

(Mahmudi 2007: 129) Rasio Efektivitas Pajak Daerah dihitung dengan cara membandingkan Realisasi penerimaan pajak daerah dengan target penerimaan pajak daerah dalam hal ini Realisasi dan Target Pajak Sarang Burung Walet dari tahun 2011-2014. Rasio ini sebagai berikut:

Adapun kriteria efektivitas sebagai berikut

\section{Table 3.1 Tabel Interpretasi Nilai Efektivitas}

\begin{tabular}{|c|c|}
\hline Presentase & Kriteria \\
\hline$>100 \%$ & Sangat efektif \\
\hline $90-100 \%$ & Efektif \\
\hline $80-90 \%$ & Cukup efektif \\
\hline $60-80 \%$ & Kurang efektif \\
\hline$<60 \%$ & Tidak efektif \\
\hline
\end{tabular}

Sumber : Depdagri, Kemendagri No. 690.900.327(Halim, dalam Ricart, (2013)

\section{Analisis Kontribusi}

Analisis yang digunakan untuk mengetahui seberapa besar kontribusi pajak sarang burung wallet terhadap total Pendapatan Asli Daerah Kabupaten Minahasa dalam kurun waktu 3 tahun yaitu dari tahun 2011-2014, yang presentasenya dihitung dari realisasi Pajak sarang burung wallet dibandingkan dengan total realisasi pendapatan asli daerah. Untuk lebih jelasnya dapat dilihat dalam rumus (Novia, dalam Sambuaga, 2011). 
Table 3.2 Klasifikasi Kriteria Kontribusi

\begin{tabular}{|c|c|}
\hline Presentase & Kriteria \\
\hline $0,00 \%-10 \%$ & Sangat kurang \\
\hline $10 \%-20 \%$ & Kurang \\
\hline $20,10 \%-30 \%$ & Sedang \\
\hline $30,10 \%-40 \%$ & Cukup Baik \\
\hline $40,10 \%-50 \%$ & Baik \\
\hline Diatas $50 \%$ & Sangat Baik \\
\hline
\end{tabular}

Sumber: Tim Litbang Depdagri-Fisipol UGM 1991

(Halim, dalam Ricart, (2013)

\section{PEMBAHASAN}

\section{Gambaran Umum Kabupaten Minahasa}

Kabupaten Minahasa adalah salah satu kabupaten di Sulawesi Utara. Ibukota kabupaten ini terletak di Tondano. Kabupaten ini memiliki luas wilayah sekitar 1.028,85 km² dengan jumlah populasi penduduk sekitar 343.014 jiwa. Kabupaten Minahasa saat ini terdiri dari 25 kecamatan, yaitu:

Visi dari kabupaten Minahasa

"Menuju Minahasa Bermartabat dan Sejahtera tahun 2018"

Misi Kabupaten Minahasa

- Menciptakan tata kelola pemerintahan yang baik dan penyelenggaraan pemerintahan yang bersih.

- Meningkatkan kualitas sumber daya manusia Minahasa yang berdaya saing dengan semboyan "Sitou Timou Tumou Tou"

- Memlihara nilai budaya Minahasa yang kreatif, produktif dan inovatif berdasarkan semangat "Mapalus"

- Meningkatkan kesejahteraan rakyat Minahasa melalui pengelolaan sumber daya alam yang efisien, efektif, dan berkelanjutan berbasis agrobisinis dan pariwisata.

\section{Gambaran Umum Pajak Sarang Burung Walet di Kabupaten Minahasa}

Sesuai ketentuan yang diatur dalam Undang-Undang Nomor 28 tahun 2009, Kabupaten Minahasa melakukan pemungutan terhadap beberapa jenis pajak daerah. Dasar hukum pelaksanaan dan pemungutan pajak sarang burung walet di Kabupaten Minahasa adalah Peraturan Daerah Kabupaten Minahasa Nomor 1 Tahun 2011 tentang Pajak Daerah Kabupaten Minahasa. Berdasarkan peraturan yang berlaku, yang menjadi objek pajak sarang burung wallet adalah pengambilan dan/atau pengusahaan sarang burung wallet. Subjek pajak sarang burung wallet adalah orang pribadi atau Badan yang melakukan pengambilan dan/atau mengusahakan sarang burung wallet, dan wajib pajaknya adalah orang pribadi atau Badan yang melakukan pengambilan dan/atau mengusahakan sarang burung wallet, dengan dasar pengenaan pajak sarang burung wallet adalah Nilai jual sarang burung wallet dan tarifnya ditetapkan sebesar 10\% (sepuluh persen). Berikut ini adalah data target dan realisasi pajak sarang burung wallet di Kabupaten Minahasa tahun 2011-2014. 
Table 4.1

Laporan Target dan Realisasi

Pajak Sarang Burung Walet di Kabupaten Minahasa Tahun 2011 - 2014

\begin{tabular}{|c|c|c|}
\hline Tahun & $\begin{array}{c}\text { Target Pajak Sarang Burung } \\
\text { Walet } \\
\text { (Rp) }\end{array}$ & $\begin{array}{c}\text { Realisasi Pajak Sarang Burung } \\
\text { Walet } \\
\text { (Rp) }\end{array}$ \\
\hline 2011 & $100,000,000$ & $22,277,800$ \\
\hline 2012 & $2,000,000,000$ & $2,192,631,800$ \\
\hline 2013 & $2,000,000,000$ & $2,596,743,000$ \\
\hline 2014 & $2,300,000,000$ & $3,644,246,400$ \\
\hline
\end{tabular}

Sumber: DIPENDA Kabupaten Minahasa, 2015

\section{Pembahasan}

\section{Efektivitas}

Berikut adalah tabel Efektivitas Pajak Sarang Burung Walet di Kabupaten Minahasa Tahun 2011 - 2014.

Table 4.2

Efektivitas Pajak Sarang Burung Walet

Kabupaten Minahasa tahun 2011-2014

\begin{tabular}{|c|c|c|c|}
\hline Tahun & $\begin{array}{c}\text { Target Pajak sarang } \\
\text { Burung Walet } \\
(\mathbf{R p})\end{array}$ & $\begin{array}{c}\text { Realisasi Pajak sarang } \\
\text { Burung Walet } \\
(\mathbf{R p})\end{array}$ & Efektivitas \\
\hline 2011 & $100,000,000$ & $22,277,800$ & $22.28 \%$ \\
\hline 2012 & $2,000,000,000$ & $2,192,631,800$ & $109.63 \%$ \\
\hline 2013 & $2,000,000,000$ & $2,596,743,000$ & $129.84 \%$ \\
\hline 2014 & $2,300,000,000$ & $3,644,246,400$ & $158.45 \%$ \\
\hline \multicolumn{4}{|c|}{ Rata - rata } \\
\hline
\end{tabular}

Sumber: Data Diolah, 2015

Berdasarkan tabel diatas dapat dilihat bahwa setiap tahun efektivitas pajak sarang burung wallet dari tahun 2011 sampai dengan 2014 mengalami peningkatan. Pada tahun 2011 tingkat efektivitas pemungutan pajak sarang burung wallet sebesar 22,28\%, kemudian pada tahun 2012 efektivitas pemungutan pajak sarang burung wallet mengalami kenaikan yaitu sebesar 109,63\%, pada tahun 2013 efektivitas pemungutan pajak sarang burung wallet juga mengalami kenaikan dari tahun sebelumnya yaitu sebesar 129,84\%, begitu juga pada tahun 2014 efektivitas pemungutan pajak sarang burung wallet juga mengalami kenaikan dari tahun-tahun sebelumnya yaitu sebesar $158,45 \%$. Walaupun pada tahun 2011 efektivitas pajak sarang burung wallet tidak mencapai target tapi pada tahuntahun berikutnya yaitu tahun 2012, 2013 dan 2014 senantiasa mencapai bahkan melebihi target (over target). Atau dengan kata lain pada tahun 2011 pajak sarang burung wallet tidak terealisasi dengan baik, dan pada tahun 2012, 2013 dan 2014 pajak surung burung wallet sudah terealisasi dengan baik.

Pencapaian efektivitas tertinggi berada di tahun 2014, dengan nilai target efektivitas yaitu 158,45\%. Sedangkan pencapaian efektivitas terendah berada di tahun 2011, dengan nilai target efektivitas yaitu $22,28 \%$. Dengan melihat rata-rata efektivitas pemungutan pajak sarang burung wallet kabupaten Minahasa yang melebihi $100 \%$ atau rata-rata sebesar 105,05\% setiap tahunnya, hal ini menunjukkan bahwa kinerja dalam pemungutan pajak sarang burung wallet di kabupaten Minahasa sangat baik. Karena realisasi pajak sarang burung wallet dalam tahun 2011 - 2014 senantiasa lebih besar dari pada target yang direncanakan.

\section{Kontribusi}

Berikut adalah tabel kontribusi pajak sarang burung wallet terhadap PAD tahun 2011 - 2014. 
Tabel 4.3

Kontribusi Pajak Sarang Burung Walet Terhadap PAD

Kabupaten Minahasa Tahun 2011 - 2014

\begin{tabular}{|c|c|c|c|}
\hline Tahun & $\begin{array}{c}\text { Realisasi Pajak sarang Burung } \\
\text { Walet } \\
(\mathbf{R p})\end{array}$ & $\begin{array}{c}\text { Pendapatan Asli Daerah } \\
\text { (PAD) } \\
(\mathbf{R p})\end{array}$ & Kontribusi \\
\hline 2011 & $22,277,800$ & $23,809,053,306$ & $0.09 \%$ \\
\hline 2012 & $2,192,631,800$ & $22,477,366,444$ & $9.75 \%$ \\
\hline 2013 & $2,596,743,000$ & $31,964,854,060$ & $8.12 \%$ \\
\hline 2014 & $3,644,246,400$ & $58,778,368,154$ & $6.20 \%$ \\
\hline \multicolumn{3}{|r|}{ Rata - rata } \\
\hline
\end{tabular}

Berdasarkan tabel diatas dapat dilihat bahwa kontribusi pajak sarang burung wallet terhadap PAD dari tahun ke tahun dari tahun 2011 -2014 terus berubah-ubah. Pada tahun 2011 kontribusi yang diberikan pajak sarang burung wallet terhadap PAD sebesar 0,09\%. Kemudian pada tahun 2012 kontribusi pajak sarang burung wallet terhadap PAD mengalami peningkatan sebesar 9,75\%. Pada tahun 2013 kontribusi pajak sarang burung wallet terhadap PAD mengalami penurunan, presentasenya hanya sebesar 8,12\%. Pada tahun 2014 kontribusi pajak sarang burung wallet terhadap PAD semakin menurun tajam, presentasenya hanya sebesar 6,20\%. Dengan kata lain untuk presentase kontribusi pajak sarang burung wallet terhadap PAD dari tahun 2011 ke tahun 2012 mengalami peningkatan. Namun, pada tahun 2012 ke tahun 2014 terus mengalami penurunan yang lumayan tajam.

Kontribusi pajak sarang burung wallet yang terbesar berada pada tahun 2012 dimana presentase kontribusinya $9,75 \%$. Sedangkan kontribusi pajak sarang burung wallet terhadap PAD yang terkecil berada di tahun 2011 yaitu hanya $0,09 \%$.

Dengan melihat presentase kontribusi yang diberikan pajak sarang burung wallet terhadap PAD dapat disimpulkan bahwa kontribusi yang diberikan oleh pajak sarang burung wallet terhadap PAD sangat sedikit.

Tabel 4.4

Kontribusi Pajak Sarang Burung Walet Terhadap PAD Kabupaten Minahasa tahun 2011-2014 (dilihat dari target)

\begin{tabular}{|c|c|c|r|}
\hline Tahun & $\begin{array}{c}\text { Target Pendapatan Asli } \\
\text { Daerah }\end{array}$ & $\begin{array}{c}\text { Target Pajak Sarang Burung } \\
\text { Walet }\end{array}$ & Kontribusi \\
\hline 2011 & $24,544,538,719$ & $100,000,000$ & $0.41 \%$ \\
\hline 2012 & $27,007,276,500$ & $2,000,000,000$ & $7.41 \%$ \\
\hline 2013 & $31,256,367,000$ & $2,000,000,000$ & $6.40 \%$ \\
\hline 2014 & $67,922,781,924$ & $2,300,000,000$ & $3.39 \%$ \\
\hline
\end{tabular}

Sumber: data diolah, 2015

Kontribusi pajak sarang burung walet terhadap PAD sangat sedikit karena setiap tahun target PAD terus ditingkatkan sementara target dari pajak sarang burung walet sangat sedikit.

Dilihat dari tabel 4.4 setiap tahun target pajak sarang burung walet hanya memberi sedikit kontribusi terhadap PAD. Pada tahun 2011 target pajak sarang burung walet memberikan kontribusi terhadap PAD sebesar 0,41\%, pada tahun 2012 sebesar 7,41\%, pada tahun 2013 sebesar 6,40\% dan pada tahun 2014 sebesar 3,39\%. Yang berarti setiap tahun target pajak sarang burung walet yang telah ditargetkan oleh pemerintah tidak memberikan kontribusi yang baik atau sangat kurang terhadap pendapatan asli daerah dikabupaten minahasa. 


\section{Kesimpulan}

\section{KESIMPULAN DAN SARAN}

Penelitian ini dimaksudkan untuk menganalisis efektivitas kemudian kontribusi terhadap Pendapatan Asli Daerah di Kabupaten Minahasa, dari analisis data yang telah dilakukan dapat di ambil beberapa kesimpulan sebagai berikut:

1. Dari hasil perhitungan efektivitas pemungutan Pajak Sarang Burung Walet menunjukkan bahwa pada tahun 2011 efektivitas Pajak sarang Burung Walet sebesar 22.28\%, tahun 2012 sebesar 109.63\%, tahun 2013 sebesar 129.84\% dan pada tahun 2014 sebesar 158.45\% dengan rata-rata pemungutan Pajak Sarang Burung Walet di Kabupaten Minahasa dari tahun 2011 sampai dengan 2014 sebesar 105.05\%, sehingga dapat disimpulkan Efektivitas Pajak Sarang Burung Walet dari tahun 2011 sampai 2014 sangat Efektif.

2. Secara keseluruhan Kontribusi Pajak Sarang Burung Walet pada tahun 2011 samapai dengan tahun 2014 memberikan kontribusi yang sangat kurang terhadap Pendapatan Asli Daerah sehingga tidak mempengaruhi Jumlah Pendapatan Asli Daerah yang diterima.

\section{Saran}

1. Secara keseluruhan tingkat efektivitas Pajak Sarang Burung Walet dari tahun 2011-2014 sudah sangat efektif. Akan tetapi sangat perlu perhatian dari pemerintah Kabupaten Minahasa untuk lebih menggali potensi dari Pajak Sarang Burung Walet sehingga dapat mempengaruhi Pendapatan Asli Daerah di Kabupaten Minahasa.

2. Untuk tetap mempertahankan tingkat efektivitas, pemerintah Kabupaten Minahasa harus melakukan sosialisasi kepada masyarakat tentang pemungutan Pajak Sarang Burung Walet dan peraturan pajak yang mengikatnya. Dengan pahamnya masyarakat tentang pajak, maka akan membawa dampak positif dalam pembayaran pajak. Pemerintah juga harus membuka pasar Sarang Burung Walet sehingga nilai jual Sarang Burung Walet semakin jelas.

3. Sementara itu untuk target pajak sarang burung walet harus ditingkatkan sesuai dengan target Pendapatan Asli Daerah Kabupaten Minahasa agar setiap tahun pajak sarang burung walet akan memberikan kontribusi yang baik.

\section{DAFTAR PUSTAKA}

Ahmad Maulana,(2012), Analisis Potensi dan Upaya Pemungutan Pajak Sarang Burung Walet di Kota Singkawang. Fakultas Ekonomi, Universitas Indonesia.

Diana, Sari. (2013), Konsep Dasar Perpajakan. Penerbit PT. Refika Aditama, Bandung.

Debi Aprilliawati, (2014), Analisis Efektivitas Pajak Parkir Terhadap Pendapatan Asli Daerah Kota Mojokerto. Fakultas Ekonomi, Universitas Negeri Surabaya.

Eko Bayu Putra, (2015), Analisis Sistem Pemungutan Pajak Sarang Burung Walet Terhadap Efektivitas Pendapatan Asli Daerah Pada Dinas Pendapatan Daerah Kota Pontianak. Fakultas Ekonomi, Universitas Tanjungpura Pontianak.

Fitria,(2012), Analisis Penerapan dan Pemungutan Pajak Penerangan Jalan, Pajak Hotel dan Pajak Sarang Burung Walet di Kabupaten Karawang, Universitas Bina Nusantara.

Haryono, Jusup, (2003), Dasar-dasar Akuntansi Jilid I Edisi Keempat. Penerbit Bagian Penerbitan Sekolah Tinggi Ilmu Ekonomi YKPN, Yogyakarta

John E. Anderson. 2009. Casino Taxation in the United States. National Tax Journal. Vol LVIII. No.2. http://www.ntanet.org/NTJ/58/2/ntj-v58n02p303-24-casino-taxation-united-states.pdf. Diakses Desember, 31, 2015.

Kieso, Weygandt, Warfield, (2011), Financial Accounting IFRS Edition.

Mardiasmo, (2011), Perpajakan, Edisi Revisi, Penerbit CV. Andi Offset, Yogyakarta.

Mardiasmo, (2009), Akuntansi Sektor Publik, Penerbit CV. Andi Offset, Yogyakarta.

Muljono, Djoko, (2009), Akuntansi Pajak, Penerbit CV. Andi Offset, Yogyakarta. 
Peraturan Daerah Kabupaten Minahasa, Peraturan Daerah Kabupaten Minahasa nomor 1 tahun 2011 Tentang Pajak Daerah

Republic Indonesia, Undang-undang Nomor 28 Tahun 2009 tentang Pajak Daerah dan Retribusi Daerah, Jakarta.

Silvy Christina, (2013), Kontribusi Pajak Sarang Burung Walet Tehadap Pendapatan Asli Daerah Kabupaten Bangka Induk, Sekolah Tinggi Ilmu Ekonomi TRISAKTI. 